river". Systematic it may be, in that the poems describe the course of the river from its source to the sea, but the description cannot possibly be described as scientific, and would yield no information useful to a geologist. Wordsworth was assuredly aware of slow processes of change, as, for example, when lakes fill with silt. But the puzzle is, I suggest, that Wordsworth showed so little geological interest, given his scientific acquaintances and the fact that he lived in a geological Mecca. I find no evidence that he developed geological theories or made systematic observations of rocks, strata, minerals or landforms.

Obviously, he loved the countryside and wrote with the pen of genius. But science was not his métier. He didn't attend meetings of the British Association, for example, where he could have consorted with scientists to his heart's content.

In point of fact, Sedgwick really wanted to see his letters published in the Lakeland Guide of his dear friend Jonathan Otley, Keswick clock repairer and amateur naturalist. But they had been promised to Wordsworth - to Sedgwick's regret. The humble Otley was a real naturalist. He guided Sedgwick to important exposures, taught him to distinguish bedding, cleavage and jointing, and proposed a threefold subdivision of the Lakeland rocks that Sedgwick adopted (and which stands to this day). In fact, judging by his field notebooks, Sedgwick spent more time in the Lakes with men like Otley, or the engineer and surveyor Joseph Fryer, than with social equivalents like Wordsworth.

What Wyatt does show successfully is Wordsworth's interest in metaphysical problems that also concerned contemporary scientists: natural causes, rates and processes of change, origins and ends, uniformity and progression, and so on. Sedgwick certainly thought about such matters. But they were subordinate to his scientific practice, and to his titanic struggles with fellow geologists, especially Murchison.

To be sure, Wyatt admirably displays the interconnections, social and mental, between the members of the community in which Sedgwick and Wordsworth moved. But, I believe, the divide between the two cultures was already emerging in the Romantic era, and attempts to reconcile them by detailed historical research, hunting for minuscule clues indicating "influences", or grand commonalities of a metaphysical nature, may not help our understanding of a largely inevitable process, already well advanced even in the early nineteenth century.

David R. Oldroyd is at the School of Science and Technology Studies, University of New South Wales, Sydney 2052, Australia.

\section{The beginning of the end}

\section{Harriet Coles}

Sex and the Origins of Death. By William R. Clark. Oxford University Press: 1996. Pp. 224. £16.99, \$22. UK publication date is 30 January.

Some organisms can survive extreme conditions in a state of suspended life or reversible death - called cryptobiosis. Encysted embryos of the brine shrimp Artemia salina kept only $2.2{ }^{\circ} \mathrm{C}$ above absolute zero for six days hatch as successfully as those kept at room temperature.

The nineteenth-century scientists who saw cryptobiosis as a possible biological basis for resurrection are forgiven by William R. Clark for being "sophomoric" (Oxford English Dictionary: "pretentious, bombastic, immature, crude and superficial"). This is a precautionary measure by the author, who asks, in the light of latetwentieth-century evolutionary and cell biology, "what is death?".

Death is variously defined by Clark as the destruction of a genome, the loss of whole-brain function, the end-point of senescence, the genetically encoded selfdeconstruction of cells (known as apoptosis), the end of a 'self' and (with due respect to Hinduism) what happens to a mouse when an elephant sits on it. In exploring each of these forms of death, Clark moves seamlessly from the rare genetic Hutchison-Gilford syndrome in which 13-year-old children die of old age, to the p53 gene as a master switch between the life and death of a cell, and the ethical dilemma of maintaining more and more people in a persistent vegetative state.

The "sex" in the title of the book is more than a marketing ploy. Clark translates the age-old conceit of sex and death (which can be traced from the poetry of John Donne to Hollywood screenplays by way of Freud) into the language of evolutionary biology. One of the earliest sexual reproducers to evolve - the single-celled organism Paramecium also evolved the programmed destruction of DNA used for cell maintenance but not of DNA set aside for reproduction. Seen from this perspective, multicellular organisms are an elaboration of this theme of division of labour into somatic and germline DNA. Clark eloquently traces the ancestral roots of both programmed cell death and, more indirectly, death of the whole organism to the evolution of sex in paramecia.

At best, this book is an enjoyable and eminently readable collection of light essays on the several definitions of death and life, but it aspires to be much more. It is the second popular book in two years by Clark (a professor of immunology at the University of California at Los Angeles), and in it he goes where the most respected investigators of apoptosis and senescence fear to tread. He tries to arrange this smorgasbord of deaths around seemingly profound statements about life such as "Death is not inextricably intertwined with the definition of life", “...in multicellular organisms death always begins with the death of single cells" and "If life is the interaction of structure with energy, then it follows that death at the level of a single cell must represent the loss of either structure or energy". However dazzling I found these brain-teasers, it was disappointing to realize I had been made giddy by nothing other than my own all-too-human desire for ultimate answers.

This absorbing collection of scientific 'death' curiosities was further undermined by a fictitious emergency-room scenario (complete with cardiac arrest, defibrillators, bleeping monitors and tense paramedics) that Clark uses to link myocardial cell death to existential oblivion. If you have to be 'profound', do it in moderation and leave out the hype.

Harriet Coles is an assistant editor of Nature.

\section{New in paperback \\ African Exodus: The Origins of Modern Humanity by Chris Stringer and Robin McKie. Pimlico, £12.50. "The defence [of the 'Out of Africa' model] is skilful and enthusiastic. Topics that often appear obscure and impenetrable to the public are made crystal-clear", Jean- Jacques Hublin, Nature 381, 658 (1996).}

Models of My Life by Herbert A. Simon. MIT Press, $\$ 22.50, £ 18.95$. “A mine of shrewd observations... the autobiography covers a period of astonishing intellectual ferment", $\mathrm{H}$. Christopher Longuet-Higgins, Nature 350, 531 (1991).

Power from Wind: A History of Windmill Technology by Richard L. Hills. CUP, £18.95, \$29.95. “An important contribution to the history of technology", A. G. Keller, Nature 372 , 627 (1994).

Image and Brain: The Resolution of the Imagery Debate by Stephen M. Kosslyn. MIT Press, \$27.50, £23.50. Reviewed by Zenon Pylyshyn in Nature 372, 289 (1994).

Hidden Attraction: The Mystery and History of Magnetism by Gerrit L. Verschuur. OUP, \$14.95, £10.99. Reviewed by L. Pearce Williams in Nature 364, 586 (1993). 